\title{
The Impact of Palm Oil Price on the Malaysian Stock Market Performance
}

\author{
*Sabariah Nordin, Norhafiza Nordin, Rusmawati Ismail \\ Universiti Utara Malaysia, Malaysia \\ *norsabariah@uum.edu.my
}

\begin{abstract}
The performance of a stock market has always become the center of attention for market analysts and investors. Due to its significant role in the economy of a country, the performance of the stock market is always associated with the economic condition of a country. Because of that, this study intends to examine the impact of commodity prices in influencing the behavior of the stock market index specifically by focusing on the palm oil prices. Since Malaysia is one of the major producers of palm oil, the behavior of the palm oil price is expected to have an influence on the Malaysian stock market index. In pursuing the objective, we have adopted the bounds test approach to analyze the existence of cointegration relationship among the underlying variables of the Malaysian stock market index, interest rate, exchange rate and the price of palm oil. Using monthly data for the period of 1997M12 to 2012M9, results of an ARDL test indicates that all the variables employed are significant in influencing the Malaysian stock market index in the long run as well as in the short run.
\end{abstract}

Keywords: Stock market index, bounds test, cointegration, palm oil price, Malaysia

\section{Introduction}

A stock market index has generally being used to indicate the performance of an economy. The rise in the stock market index has always been associated with the booming of the market and vice versa. Since a stock market index measures the performance of stock prices, fluctuations in the existing stocks' prices are indeed being reflected in the stock market index. Nevertheless, the fluctuation in the index is found to be affected not just by the prices of the existing selected stocks, but also by some other macroeconomic variables and commodity prices which have potential influence on the stock prices. Most studies have been considering oil price as a proxy for commodity price as one of their potential determinants of the stock market performance (Valadkhani, Chancharat \& Havie, 2009). However, for this study, we intend to examine the potential effect of the palm oil industry on the Malaysian stock market. The palm oil industry is considered to be one of the major sub-sectors of agricultural industry for Malaysia. Currently, Malaysia is accounted for 39 percent of world palm oil production and 44 percent of world exports (information available at http://www.mpoc.org.my as of 22 September 2013). The significance of the palm oil industry can be observed from its contribution to the exports and the establishment of derivative instruments on the underlying asset of palm oil, for instance the Crude Palm Oil Futures which is traded on the Bursa Malaysia.

In addition to assessing the potential effect of the palm oil price on the Malaysian stock market index, this study will also consider two potential determinants of stock market index namely interest rate and exchange rate which have been considered extensively in past empirical studies. The rise in the price of palm oil is expected to enhance the performance of the FBMKLCI. The interest rate is expected to have a negative relationship while the exchange rate is expected to have either a positive or a negative relationship with the index. The organization of the study is as follows. The first section provides introduction to the topic. The second section discusses the theoretical framework of the study in which it helps to explain the rationale behind the selection of the variables. The third section reviews literature related to the study. The fourth section discusses the methodology being adopted in this study. The fifth and the last sections discuss the results and conclude the study respectively.

Theoretical Framework: Since the stock market index measures the stock price, theories applicable to this study would be those focusing on the behavior of the stock price and also market reaction. In addition, the selection of variables adopted for this study is also being determined based on past empirical studies. 
Efficient Market Hypothesis Theory: Efficient Market Hypothesis (EMH) implies that asset prices promptly reflect all available information. Given that the market is efficient, abnormal profits cannot be attained regardless of any investment strategy adopted. According to Fama (1970), there are three types of market efficiency namely weak, semi-strong and strong forms of market efficiency which later have been identified as predictability, event studies and inside information respectively (Fama, 1991). The weak form of the market efficiency asserts that asset prices integrate all relevant past information. The semi-strong form indicates that the asset prices not just reflect past information, but also other information available to the public. Finally, the strong form of market efficiency implies that asset prices not just reflect past and public information, but also private information particularly those specifically related to the company. Given that the market is efficient, at least in the weak form of market efficiency, the return an investor earns on his investment cannot be predicted because it follows a random walk. For the purpose of this study, our focus will concentrate more on the past or historical information. So, our application here is more on the weak form of market efficiency which is easier to measure and the data is easier to obtain. Since asset prices do fluctuate, we will integrate relevant macroeconomic variables determined from past empirical studies and a commodity price which we believe have potential effect on the behavior of the asset price movements.

Arbitrage Pricing Theory: Arbitrage Pricing Theory (APT) is a theory that demonstrates the price of an asset given relevant risks. APT can be expressed as:

$$
R_{i t}=r f_{t}+\beta_{i} X_{t}+\varepsilon_{t}
$$

Where $R_{i t}$ is the return of stock $i$ at time $t, r f$ is the risk free interest rate at time $t$ and $X$ is a vector of predetermined economic factors at time $t$. $\beta_{i}$ measures the sensitivity of the stock to the changes that happen to each economic factor defined by the equation. $\varepsilon$ is the error term at time $t$. Since APT does not specify the type of macroeconomic variables to be included in the model, the selection of variables will be based on past empirical studies and the rationale of considering that variable as part of the model. Specifically, in addition to the stock market index as the dependent variable, this study will consider interest rate, exchange rate and the price of palm oil as independent variables. Since an asset price fluctuates as indicated by the efficient market hypothesis theory, and this fluctuation is affected by a number of predetermined economic factors as indicated by the arbitrage pricing theory, this study intends to examine the impact of interest rate, exchange rate and the price of palm oil on the Malaysian stock market index. An interest rate is always associated with investment in the fixed income instruments such as bonds, and an increase in the interest rate would redirect investors from investing in the stock market towards investing in the fixed income securities. In addition, interest rate is also considered as a cost of financing; the higher the cost, the lower will be the borrowings. Due to the lack of funds, there will also be less demand for the stocks which at the end will affect the price of the stock. Since the index is a representation of a group of stocks, the impact on the stock prices will be reflected in the index. In short, the interest rate is expected to have a negative relationship with the stock market index.

Another economic variable that has been used extensively in the studies of the stock market performance is the exchange rate. An exchange rate represents the price of one currency against another currency. Theory suggests that as the local currency depreciates with respect to foreign currencies, the stock market index should increase as domestic goods become highly competitive compared to foreign goods. Besides, the cheaper value of domestic currency would also allow foreign investors to penetrate the market. This condition would represent a potential positive effect of exchange rate, which represents the depreciation of the local currency, on the stock market index. Nevertheless, the exchange rate may also affect the stock market negatively through the appreciation of the local currency. In this case, an appreciation of the local currency gives a signal to investors that the market is worth invested in. In short, the expected sign for the exchange rate can be positive or negative. Finally, the variable that will become the main focus of this study is the palm oil. Since the palm oil constitutes one of the major exports for Malaysia, fluctuations in its prices are expected to affect the Malaysian stock market performance. An increase in the palm oil price, which is reflected by the increase in the demand, is expected to enhance the performance of the Malaysian stock market index. 


\section{Literature Review}

Financial market history shows that stock price is subjected to substantial fluctuations. Generally, stock price will move up when there are good news, and move down when there are bad news. The news can be from the market itself, the economy or from the events that happen in the company. In that case, there are a lot factors that can be considered to examine the fluctuations in the stock market. In order to verify which variables to be selected for this particular study, this section would provide a review on past literature. Even though there are a lot of studies examining the stock price behavior, country of study, period of study and the technique used may influence the results. In examining the long run and short run relationships between macroeconomic variables and the Malaysian stock market index, Bekhet and Mugableh (2012) discover that there is a cointegration relationship between macroeconomic variables of GDP, producer price index, CPI, M3 and exchange rate with the Malaysian stock market index for the period of 1977 to 2011. The PPI, CPI, exchange rate and M3 are found to have negative relationships with the stock market index, while the GDP is found to have a positive relationship with the stock market index in the long run. For the short run results, only GDP is found to exert a significant positive impact on the stock market index. Similarly, Rahman, Sidek and Tafri (2009) examine the relationship that exists among the Malaysian stock market index and selected macroeconomic variables for the monthly data of January 1986 to March 2008. Their VECM results indicate that there is cointegration relationship between the Malaysian stock market index and macroeconomic variables of money supply, interest rate, exchange rate, reserves and industrial production index. In addition, their study also shows that the Malaysian stock market has stronger dynamic interaction with reserves and industrial production index as opposed to money supply, interest rate and exchange rate.

In a different study, Eita (2012) investigates the macroeconomic determinants of Namibian stock market prices for the period of 1998 to 2009. Using the VECM approach, she discovers that the Namibian stock market is influenced by economic activity, interest rates, inflation, money supply and exchange rates. Unlike Bekhet and Mugableh (2012), money supply is found to have a positive significant impact on the stock market index. Economic activity is found to have a positive relationship with the stock market prices, while inflation and interest rates are found to have negative relationships with the stock market prices. Fathi et al. (2012) conduct a study to examine the impact of macroeconomic variables of national income, investment rate, financial intermediary development and macroeconomic stability on the Tehran Stock Exchange. The period of study is between 1998 and 2007. In addition to the existence of cointegration relationship among the underlying variables, results also indicate that national income and investment rates to have a positive significant effect on the depth and breadth of the Tehran Stock Exchange. On the other hand, financial intermediary development and macroeconomic stability are found to have a significant negative effect on the stock exchange. In a different way, Hsing, Budden and Phillips (2012) apply the exponential GARCH model to examine the relationship between macroeconomics and the Argentine stock market index for a quarterly sample of 1998Q1 to 2011Q2. Their findings indicate that real GDP, the ratio of M2 to GDP, the exchange rate of peso/USD and the US stock market index have positive relationships with the Argentine stock market index. Conversely, the money market rate, government spending as a percentage of GDP and inflation rate are found to have negative relationships with the Argentine stock market index.

In a different study, Sohail and Zakir (2012) try to evaluate the impact of the macroeconomic variables on three different stock exchanges in Pakistan, namely Karachi, Lahore and Islamabad stock exchanges. Their macroeconomic variables are represented by industrial production index, consumer price index, money supply, real effective exchange rate and three months treasury bills rate. In assessing the long run relationship among the underlying variables, they employ Johansen cointegration technique. Their results indicate that the industrial production index has a positive relationship with stock prices in all three stock exchanges. The exchange rate is found to positively affect stock prices in Karachi and Lahore's indices, but a significant negative impact on the Islamabad index. Inflation is found to have a positive impact on the stock price of Karachi stock exchange, but a negative impact on the other two indices. The money supply shows a negative impact on the indices of Karachi and Islamabad, but a positive impact on the Lahore index. The treasury bills rate has a positive impact on the Lahore and Islamabad indices. Mehr-un-Nisa and Nishat (2011) examine empirical relationship between the stock prices, financial fundamentals and macroeconomic factors by focusing on the Karachi Stock Exchange. By employing the dynamic panel Generalized Method of Moments (GMM) on 221 firms for the period of 1995 to 2006; their results indicate the significance of 
earnings per share and a company's size in influencing the stock price. In addition, real GDP growth, interest rate and financial development are also found to significantly influence the stock price.

Sohail and Zakir (2010) explore the impact of five macroeconomic variables, namely consumer price index, real effective exchange rate, industrial production index, money supply and treasury bills rate, on the general index of the Karachi Stock Exchange. By employing the Johansen cointegration technique and the VECM approach, they discover that the CPI, real effective exchange rate and industrial production index have a positive impact on the stock prices in Pakistan. On the other hand, money supply and the treasury bills rate are found to negatively affect the stock price in the long run. Meanwhile, Kyereboah-Coleman and AgyireTettey (2008) study the relationship between macroeconomic indicators and the Ghana stock exchange market. Using quarterly data for the period of 1991 to 2005, they indicate the presence of cointegration relationship between the Ghana stock exchange index and inflation, real exchange rate, interest rate and a dummy variable of a listed company. All variables are found to be statistically significant in affecting the GSE index with the inflation and lending rates showing a negative relationship, while the exchange rate showing a positive relationship. Lee, Boon and Baharumshah (2001) explore the dynamic linkages between Kuala Lumpur Stock Exchange stock prices and microeconomic fundamentals prior to the 1997 Asian crisis. They discover that the macroeconomic fundamentals of inflation rate, interest rate, industrial production index, money supply, exchange rates and trade balance are vital in determining the movements in stock prices in the short run as well as in the long run. Their results suggest that the Composite Index, Industrial Index, Plantation Index and the Mining Index to be inflation-sensitive securities, while the Composite Index and Industrial Index are output sensitive. The trade balance is also found to significantly influence the stock prices.

Differently, Majid and Yusof (2009) focus their study on the Islamic stock market. They perform a study to explore the extent to which macroeconomic variables affect the Islamic stock market in Malaysia in the post 1997 Asian financial crisis period. By employing the autoregressive distributed lag (ARDL) approach, their results suggest that real effective exchange rate, money supply of $\mathrm{M} 3$, treasury bill rate and federal fund rate of the US monetary policy should be the variables to focus on in order to stabilize the Islamic stock market and encourage more capital into the market. Unlike other studies on conventional stock market indexes, they exert a positive relationship between interest rates and the Islamic stock prices. Similar to Majid and Yusof (2009), Hussin et al. (2012) study the relationship that exists between the development of Islamic stock market and macroeconomic variables in Malaysia. By employing the Vector Auto Regression (VAR) method, they discover that the Islamic stock prices are cointegrated with the underlying variables of industrial production index, consumer price index, money supply, Islamic interbank rate and exchange rate. IPI and CPI show significant positive relationship with the Kuala Lumpur Syariah Index, while M3 and exchange rate have a significant negative relationship with the Islamic index. There is no significant relationship found between the Islamic index and the Islamic inter-bank rate.

In the meantime, Muhammad, Ghuslan and Jusoff (2009) conduct a study to examine the long run relationship between the Malaysian stock market and the performance of the agricultural sector which is represented by the Plantation index for the daily data of 1990 to 2005. Using Johansen cointegration test and the Vector Error Correction Model (VECM), their results indicate that there is a positive long run relationship between the Malaysian stock market and the agricultural sector. In a different way, Valadkhani, Chancharat and Havie (2009) analyze the effect of various international stock market price indices and macroeconomic variables on the Thai stock market price index. In pursuing the objective, they apply a GARCH-M model and monthly data of January 1988 to December 2004. Their results indicate that changes in the stock market returns in Singapore have a positive impact on the Thai stock market in both pre- and post-1997 crisis period. Changes in the stock market returns in Malaysia and Indonesia prior to 1997 Asian crisis, and changes in stock market returns in Philippines and Korea in the post-1997 influence the return in the Thai stock market. Stock markets outside the region have no significant impact on the Thai stock market. Changes in the price of crude oil have a negative impact on the Thai stock market in the pre-Asian crisis period. Macroeconomic variables of CPI, exchange rate, interest rate and money supply have no significant impact on the Thai stock market. 


\section{Methodology}

This study employs the bounds test approach to examine the existence of cointegration relationship among underlying variables of stock market index, interbank rate, exchange rate and the price of palm oil. In addition, this study also reports long run and short run coefficients of the underlying variables in influencing the performance of the stock market index.

Data: This study will focus on four main variables namely stock market index as represented by the FBMKLCI index (KLCI), 3 months interbank rate (IBR), exchange rates of RM/USD (EXR) and the price of palm oil (POIL). This study focuses on the stock market index as a function of IBR, EXR and POIL. This study employs monthly data for the period of 1997M12 to 2012M9. The data on interest rate, exchange rate and stock market index are gathered from the database of Datastream, while the data on the price of palm oil is gathered from the World Bank commodity price. All variables are in the logarithm form except for the interest rate.

General Model:

LKLCI $=\mathrm{f}(\mathrm{IBR}, \mathrm{LEXR}, \mathrm{LPOIL})$

$\mathrm{LKLCI}=\beta_{0}+\beta_{1} \mathrm{IBR}_{\mathrm{t}}+\beta_{2} \mathrm{LEXR}_{\mathrm{t}}+\beta_{3} \mathrm{LPOIL}_{\mathrm{t}}+\varepsilon_{\mathrm{t}}$

Where

$\begin{array}{lll}\text { LKLCI } & = & \text { Logarithm of FBMKLCI index at time } t \\ \text { IBR } & = & 3 \text { months interbank rate at time } t \\ \text { LEXR } & = & \text { Logarithm of exchange rate (RM/USD) at time } t \\ \text { LPOIL } & = & \text { Logarithm of palm oil price at time } t \\ \varepsilon & = & \text { error term at time } t\end{array}$

Figure 1 illustrates the behavior of the selected variables for the study period. All variables, which initially perform the function of price, fluctuate. Since the period of study used starts with the period where the 19971998 Asian financial crises happened, we could see some kind of trend in the data. For instance, the FBMKLCI index started with the lowest amount in the beginning, then started to relatively increase despite the fluctuations that happen throughout the period of study. The interest rate started with the highest rate and significantly dropped after the crisis before showing low variability in the rates. The crisis brought a significant negative impact on the currency value which shows that the RM had depreciated a lot at the beginning stage of the period before starting to gain confidence in the value later. The price of palm oil also shows a significant drop after the crisis before starting to gain a good momentum again later.

Figure 1: Multiple Line Graphs
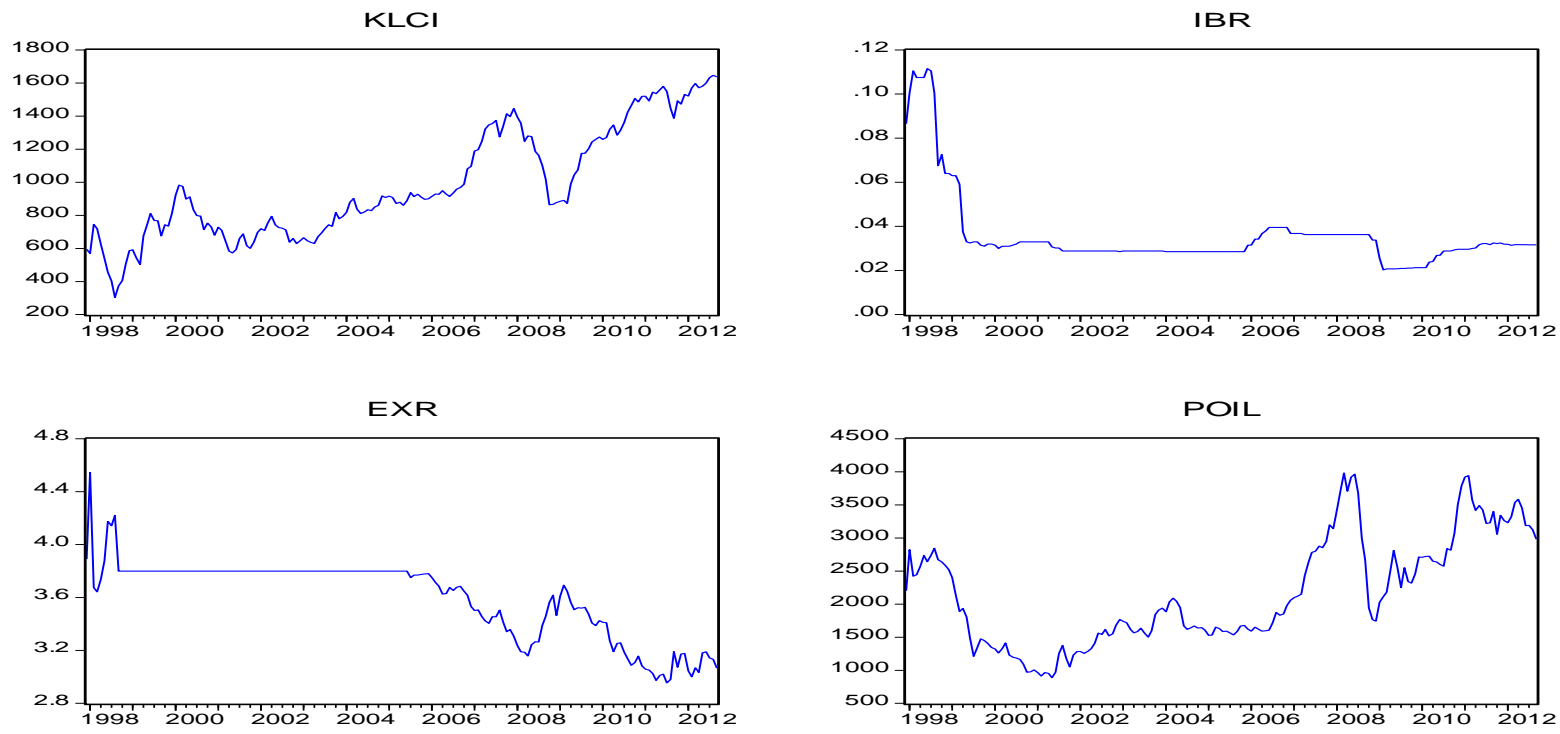
Table 1 highlights descriptive statistics of the underlying variables. Variances for interest rate and exchange rate are low compared to variances indicated by the stock market index and the price of palm oil which are more than 10 percent (based on the square of standard deviation of each variable).

Table 1: Descriptive Statistics

\begin{tabular}{|c|c|c|c|c|}
\hline & LKLCI & IBR & LEXR & LPOIL \\
\hline Mean & 6.827940 & 0.035790 & 1.277164 & 7.606663 \\
\hline Median & 6.801361 & 0.031450 & 1.329499 & 7.568430 \\
\hline Maximum & 7.406170 & 0.111500 & 1.514028 & 8.289335 \\
\hline Minimum & 5.713436 & 0.020300 & 1.083668 & 6.790322 \\
\hline Std. Dev. & 0.346612 & 0.017869 & 0.083703 & 0.380904 \\
\hline Skewness & -0.206132 & 3.130804 & -0.703968 & -0.052113 \\
\hline Kurtosis & 2.671927 & 12.39912 & 2.707925 & 2.072100 \\
\hline Jarque-Bera & 2.058816 & 946.0053 & 15.33464 & 6.466310 \\
\hline Probability & 0.357218 & 0.000000 & 0.000468 & 0.039433 \\
\hline
\end{tabular}

The correlation matrix implies that the interest rate and the exchange rate have negative relationships with the FBMKLCI index, while the price of palm oil has a positive relationship with the FBMKLCI index (Table 2). The interest rate is found to have a positive relationship with exchange rate and the price of palm oil. The correlation matrix also shows that there is a negative relationship between exchange rate and the price of palm oil.

Table 2: Correlation Matrix

\begin{tabular}{lllll}
\hline & LKLCI & IBR & LEXR & LPOIL \\
\hline LKLCI & 1 & & & \\
IBR & -0.45266364 & 1 & & \\
LEXR & -0.87970181 & 0.28763473 & 1 & \\
LPOIL & 0.60830908 & 0.18901821 & -0.73406623 & 1 \\
\hline
\end{tabular}

Estimation Technique: Since the model is regressed based on the bounds test cointegration approach, equation (2) highlights long run and short run coefficients of the model. The estimation in equation (2) is derived based on the general model of equation (1).

$$
\begin{aligned}
\Delta L K L C I_{t}=c+ & \beta_{1} L K L C I_{t-1}+\beta_{2} I B R_{t-1}+\beta_{3} L E X R_{t-1}+\beta_{4} L P O I L_{t-1} \\
& +\sum_{i=1}^{p} \alpha_{1 i} \Delta L K L C I_{t-i}+\sum_{i=0}^{p} \alpha_{2 i} \Delta I B R_{t-i}+\sum_{i=0}^{p} \alpha_{3 i} \Delta L E X R_{t-i}+\sum_{i=0}^{p} \alpha_{4 i} \Delta L P O I L_{t-i}+\varepsilon_{i}
\end{aligned}
$$

Where $p$ is the optimum lag length.

The hypotheses of the bounds test are as follows:

$$
H_{o}: \beta_{1}=\beta_{2}=\beta_{3}=\beta_{4}=0 \text { (no long run relationship) }
$$

$H_{A}: \beta_{1} \neq \beta_{2} \neq \beta_{3} \neq \beta_{4} \neq 0$ (long run relationship exists)

\section{Results and Discussion}

Table 3 highlights the results of unit root tests of Augmented Dickey-Fuller (ADF), Phillips-Perron (PP) and Kwiatkowski-Phillips-Schmidt-Shin (KPSS). Even though the bounds test approach does not stress on the importance of knowing the order of integration of the underlying variables, there is still a need to examine the variables in terms of their stationarity in order to avoid having an $I(2)$ variables. Besides, the bounds test also require the dependent variable, in this case the stock market index, to be I(1). Results in Table 3 indicate that generally all underlying variables fall under the categories of $I(0)$ or $I(1)$; all variables are generally $I(1)$ except for the interbank rate which is $I(0)$. In that case, we proceeds with the cointegration test. 
Table 3: Results of Unit Root Tests

\begin{tabular}{|c|c|c|c|c|}
\hline \multicolumn{3}{|c|}{ Augmented Dickey-Fuller (ADF) } & \multirow{2}{*}{\multicolumn{2}{|c|}{ Intercept and Trend }} \\
\hline & \multicolumn{2}{|c|}{ Intercept } & & \\
\hline & Level & First Difference & Level & First Difference \\
\hline LKLCI & -1.132939 & $-10.93815^{* * *}$ & -2.952335 & $-10.90700^{* * *}$ \\
\hline IBR & $-10.38426 * * *$ & $-5.724788^{* * *}$ & $-9.931318^{* * *}$ & $-5.677467^{* * *}$ \\
\hline LEXR & -1.786350 & $-19.50550 * * *$ & $-4.218958^{* * *}$ & $-19.44515^{* * *}$ \\
\hline \multirow[t]{4}{*}{ LPOIL } & -1.693257 & $-9.177643^{* * *}$ & $-3.275871^{*}$ & $-9.194944 * * *$ \\
\hline & \multicolumn{4}{|c|}{ Phillips-Perron (PP) } \\
\hline & \multicolumn{2}{|l|}{ Intercept } & \multicolumn{2}{|c|}{ Intercept and Trend } \\
\hline & Level & First Difference & Level & First Difference \\
\hline LKLCI & -1.347394 & $-10.77138^{* * *}$ & $-3.418295^{*}$ & $-10.73613^{* * *}$ \\
\hline IBR & $-2.880068^{* *}$ & $-11.32067^{* * *}$ & -2.440740 & $-11.58136^{* * *}$ \\
\hline LEXR & -1.462598 & $-21.90043^{* * *}$ & $-4.077202^{* * *}$ & $-21.51435^{* * *}$ \\
\hline LPOIL & -1.460061 & $-10.68225^{* * *}$ & -2.484788 & $-10.72007^{* * *}$ \\
\hline \multicolumn{5}{|c|}{ Kwiatkowski-Phillips-Schmidt-Shin (KPSS) } \\
\hline & \multicolumn{2}{|c|}{ Intercept } & \multicolumn{2}{|c|}{ Intercept and Trend } \\
\hline & Level & First Difference & Level & First Difference \\
\hline LKLCI & $1.473202^{* * *}$ & 0.029139 & 0.061672 & 0.024554 \\
\hline IBR & $0.521394 * *$ & 0.245557 & $0.192457^{* *}$ & 0.078368 \\
\hline LEXR & $1.411035^{* * *}$ & 0.314514 & $0.259995^{* * *}$ & $0.289239 * * *$ \\
\hline LPOIL & $0.972168^{* * *}$ & 0.114955 & $0.185117^{* *}$ & 0.061710 \\
\hline
\end{tabular}

Note: ${ }^{*}, *$ and ${ }^{* * *}$ represent $10 \%, 5 \%$ and $1 \%$ significance levels respectively.

Results in Table 4 indicate that there is a cointegration relationship among the underlying variables of stock market index, interest rate, exchange rate and palm oil price. The cointegration relationship points out that the underlying variables display a long run equilibrium relationship in which they do not deviate far from each other. Their short run adjustments will restore their equilibrium relationship in the long run. As indicated in Table 4, the F-statistic of 6.9883 is greater that the I(1) critical value of 5.960 at 1 percent significance level. This result indicates the existence of the cointegration relationship among the underlying variables.

Table 4: Results of Bounds Test for Cointegration Analysis

\begin{tabular}{|c|c|c|c|}
\hline $\begin{array}{l}\text { Dependent variable: } \\
\text { LKLCI }\end{array}$ & $\begin{array}{c}\text { F-statistic } \\
6.9883^{* * *} \\
\text { (unres }\end{array}$ & $\begin{array}{l}\text { Case III } \\
\text { icted intercept and no }\end{array}$ & trend) \\
\hline Narayan (2005) & & $k=3$ & \\
\hline Critical Value $(n=80)$ & $I(0)$ & & $I(1)$ \\
\hline $1 \%$ & 4.568 & & 5.960 \\
\hline $5 \%$ & 3.363 & & 4.515 \\
\hline $10 \%$ & 2.823 & & 3.885 \\
\hline
\end{tabular}

Note: ${ }^{* * *}$ represents significance at the $1 \%$ level. Critical values are cited from Narayan (2005). Since Narayan (2005) does not provide critical values for $n=178$, critical values of $n=80$ (the maximum available number of observations) are reported as a benchmark. It is noted that the critical values of $n=178$ should be lower than the critical values of $n=80$.

Table 5 reports the long run and short run coefficients of the model. Results of long run estimates indicate that there is a significant negative relationship between the stock market index with the interest rate as well as the exchange rate at 1 percent and 5 percent significance levels respectively. As expected, the palm oil price is found to have a positive significant impact on the stock market index at 5 percent significance level. A 1 percent increase in the palm oil price will be reflected in an increase by 0.36 percent in the KLCI index. Similarly, the short run estimates as indicated by the error correction estimates report consistent findings with the long run estimates where there is a negative significant relationship between the stock market index and the interest rate as well as the exchange rate at 1 percent significance level. Even the palm oil price shows 
consistent result where there is a positive significant relationship between the palm oil price and the stock market index at 5 percent significance level. The short run adjustment indicates that a 1 percent increase in the price of palm oil will be reflected in an increase by 0.05 percent in the KLCI index. As indicated in Table 5 , the error correction term is significant at 1 percent significance level with the correct negative sign. The error correction term of 0.14 indicates that roughly 14 percent of last year's deviation is corrected this year.

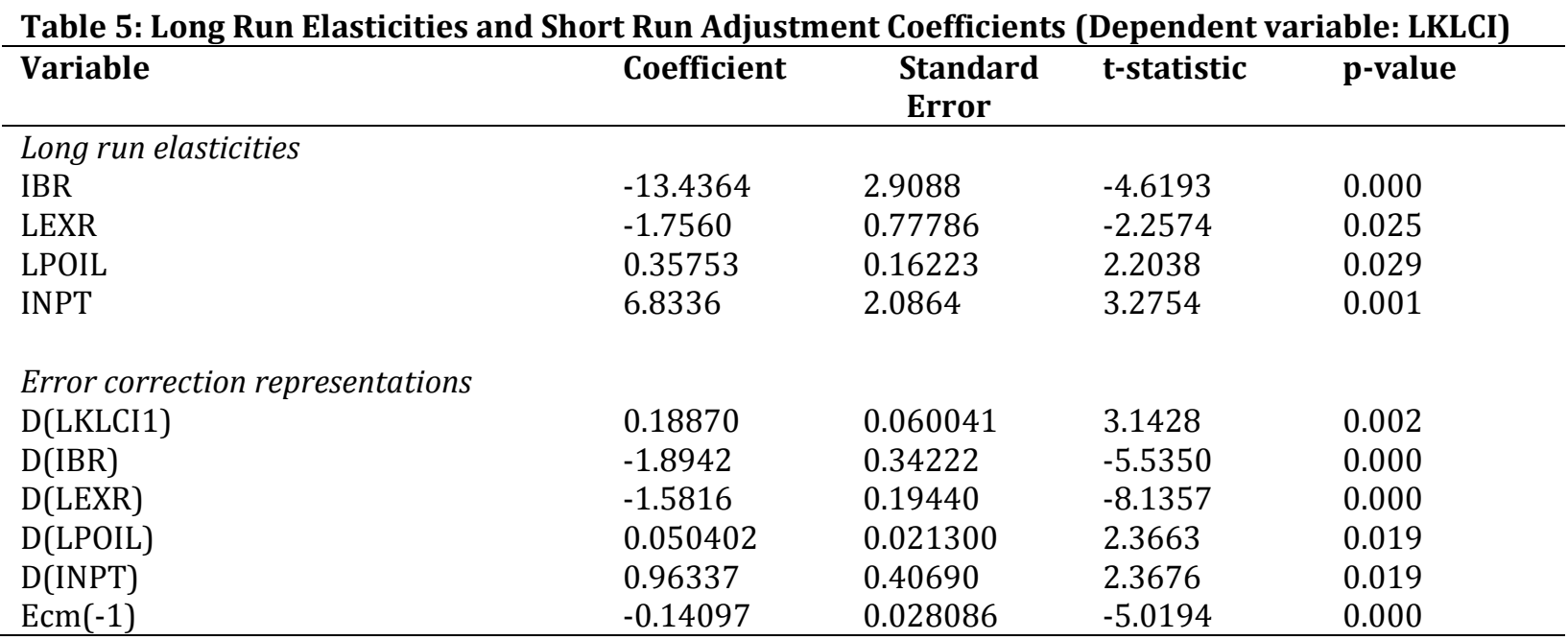

Note: The error correction representations imply short run coefficients or short run adjustment towards equilibrium.

Table 6 provides the diagnostic test results for the model based on two estimations namely the OLS estimation (p,p,p,p) and also the ARDL estimation (p, q, r, s). The OLS and ARDL estimations indicate that the model fails the normality assumption. However, Paruolo (1997) (cited in MacDonald \& Ricci, 2003) argues that non-normality as a result of excess kurtosis does not affect the results. The ARDL estimation also shows that the model fails the heteroscedasticity test. Nevertheless, according to Shrestha and Chowdhury (2005), since ARDL models can consist of a combination of $I(0)$ and $I(1)$ variables, it would be natural to detect heteroscedasticity.

Table 6: Diagnostic Tests

\begin{tabular}{llc}
\hline Test Statistics & $\begin{array}{l}\text { OLS Estimation } \\
\text { LM }\end{array}$ & \multicolumn{2}{l}{ ARDL Estimation } \\
LM
\end{tabular}

Note: numbers in parentheses ( ) are probabilities.

\section{Conclusion}

The stock market index is normally used to indicate the economic performance of a country. Due to the significant role of the stock market in the economy, many studies attempt to investigate the factors that influence the behavior or the movement of the stock market index. Many studies have been investigating the impact of macroeconomic variables on the stock market index, and there are also studies exploring the impact of commodity prices on the stock market performance. This study investigates the impact of selected macroeconomic variables namely interest rate and exchange on the stock market price. Additionally, this study also investigates the role played by the commodity price in influencing the stock market index, and this study has chosen the palm oil price as the potential determinant of the stock market index. By employing the bounds test approach, results indicate that the underlying variables of Malaysian FBMKLCI, 3 months interbank rate, exchange rate of RM/USD and the price of palm oil are cointegrated. The long run and short run estimations also indicate the significance of all the variables in influencing the performance of the 
Malaysian stock market. Similar to some other studies, the interest rate and the exchange rate are found to be negatively significant (Lee et al., 2001; Eita, 2012; Bekhet \& Mugableh, 2012). The price of palm oil is positively significant in influencing the stock market index. These results provide some indication to the policy maker on which variables to focus on when they want to influence the stock market index.

\section{References}

Bekhet, H. A. \& Mugableh, M. I. (2012). Investigating Equilibrium Relationship between Macroeconomic Variables and Malaysian Stock Market Index through Bounds Tests Approach. International Journal of Economics and Finance, 4(10), 69-81.

Eita, J. H. (2012). Modeling Macroeconomic Determinants of Stock Market Prices: Evidence from Namibia. Journal of Applied Business Research, 28(5), 871-884.

Fama, E. F. (1970). Efficient Capital Markets: A Review of Theory and Empirical Work. The Journal of Finance, 25(2), 383-417.

Fama, E. F. (1991). Efficient Capital Markets: II. The Journal of Finance, 46(5), 1575-1617.

Fathi, S., Sameti, M., Nouri, B. A. \& Esfahani, S. S. (2012). Examining the Effect of Selective Macroeconomic Variables on the Stock Exchange's Depth and Breadth (Case Study: Tehran Stock Exchange). International Journal of Economics and Finance, 4(3), 97-104.

Hsing, Y., Budden, M. C. \& Phillips, A. S. (2012). Macroeconomic Determinants of the Stock Market Index for a Major Latin American Country and Policy Implications. Business and Economic Research, 2(1).

Hussin, M. Y. M., Muhammad, F., Abu, M. F. \& Awang, S. A. (2012). Macroeconomic Variables and Malaysian Islamic Stock Market: A Time Series Analysis. Journal of Business Studies Quarterly, 3(4), 1-13.

Kyereboah-Coleman, A. \& Agyire-Tettey, K. F. (2008). Impact of Macroeconomic Indicators on Stock Market Performance. The Journal of Risk Finance, 9(4), 365-378.

Lee, C. L., Boon, T. H. \& Baharumshah, A. Z. (2001). The Stock Market, Macroeconomic Fundamentals and Economic Growth in Malaysia. Asia Pacific Journal of Economics and Business, 5(2), 44-55.

MacDonald, R. \& Ricci, L. (2003). Estimation of the Equilibrium Real Exchange Rate for South Africa, IMF Working Paper WP/03/44.

Majid, M. S. A. \& Yusof, R. M. (2009). Long-run Relationship Between Islamic Stock Returns and Macroeconomic Variables. Humanomics, 25(2), 127-141.

Mehr-un-Nisa, L. \& Nishat, M. (2011). The Determinants of Stock Prices in Pakistan. Asian Economic and Financial Review, 1(4), 276-291.

Muhammad, J., Ghuslan, M. I. \& Jusoff, K. (2009). Long Run Relationship between Malaysian Stock Market and Agriculture Sector. Interdisciplinary Journal of Contemporary Research in Business, 1(6), 157-171.

Rahman, A. A., Sidek, N. Z. M. \& Tafri, F. H. (2009). Macroeconomic Determinants of Malaysian Stock Market. African Journal of Business Management, 3(3), 095-106.

Shrestha, M. B. \& Chowdhury, K. (2005). ARDL Modeling Approach to Testing the Financial Liberalization Hypothesis. Economics Working Paper Series 2005, University of Wollongong

Sohail, N. \& Hussain, Z. (2012). Macroeconomic Policies and Stock Returns in Pakistan: A Comparative Analysis of Three Stock Exchanges. Interdisciplinary Journal of Contemporary Research in Business, 3(10), 905-918.

Sohail, N. \& Zakir, H. (2010). Macroeconomic Determinants of Stock Returns in Pakistan: The Case of Karachi Stock Exchange. Journal of Advanced Studies in Finance, 1(2,2), 181-187.

Valadkhani, A., Chancharat, S. \& Havie, C. (2009). Analyzing the Impact of International Stock Markets and Macroeconomic Variables on the Thai Stock Market. The Business Review, Cambridge, 12(2), 50-56. 